This item was submitted to Loughborough's Research Repository by the author.

Items in Figshare are protected by copyright, with all rights reserved, unless otherwise indicated.

\title{
Revealing the expectations and preferences of complaining customers by combining the laddering interviewing technique with the Kano model of customer satisfaction
}

\section{PLEASE CITE THE PUBLISHED VERSION}

http://dx.doi.org/10.1108/13522750810901501

\section{PUBLISHER}

(C) Emerald Group Publishing Limited

\section{VERSION}

AM (Accepted Manuscript)

\section{LICENCE}

CC BY-NC-ND 4.0

\section{REPOSITORY RECORD}

Gruber, Thorsten, Alexander E. Reppel, Isabelle Szmigin, and Roediger Voss. 2019. "Revealing the Expectations and Preferences of Complaining Customers by Combining the Laddering Interviewing Technique with the Kano Model of Customer Satisfaction". figshare. https://hdl.handle.net/2134/11927. 
This item was submitted to Loughborough's Institutional Repository (https://dspace.lboro.ac.uk/) by the author and is made available under the following Creative Commons Licence conditions.

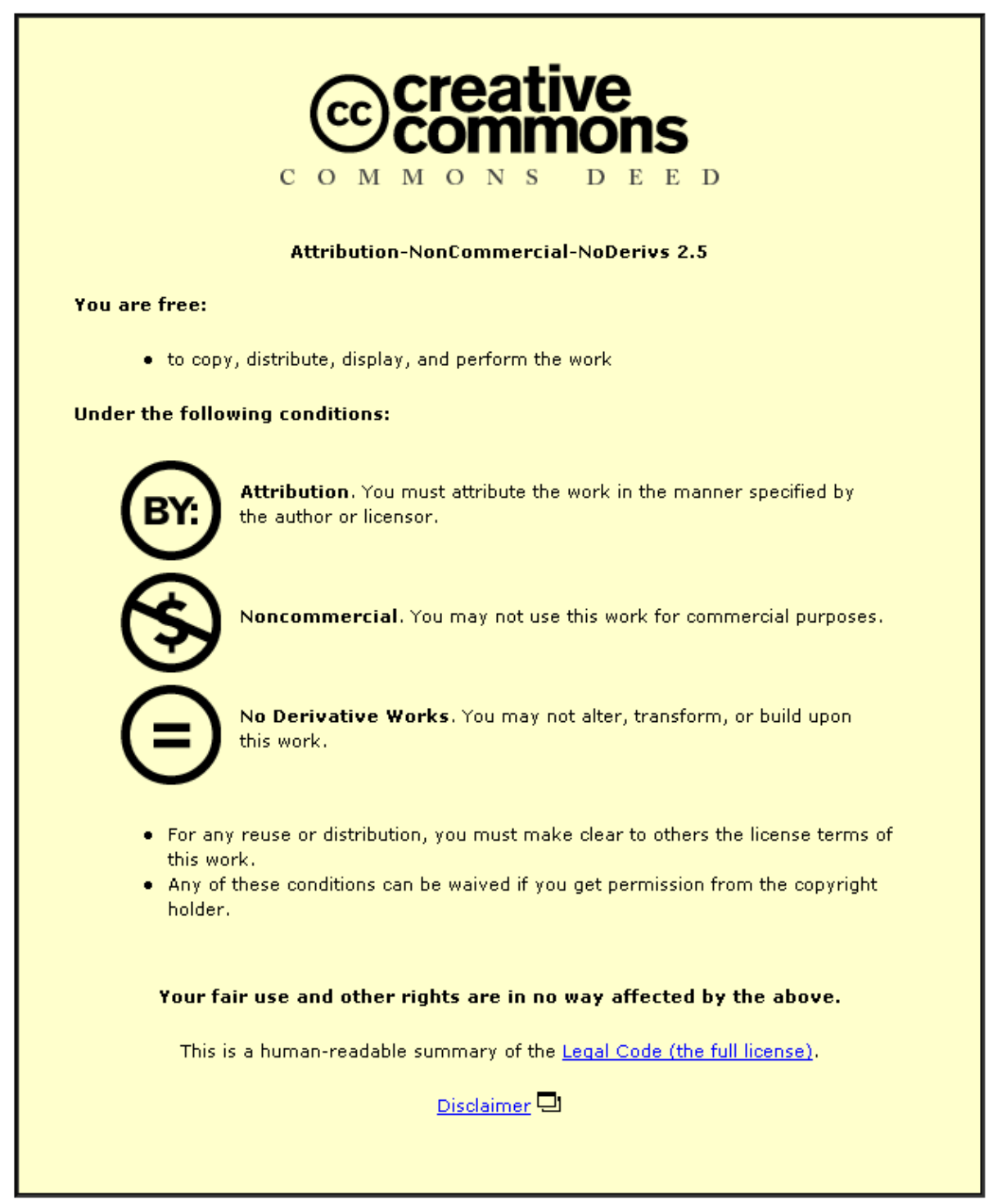

For the full text of this licence, please go to: http://creativecommons.org/licenses/by-nc-nd/2.5/ 


\section{Revealing the Expectations and Preferences of Complaining Customers by}

Combining the Laddering Interviewing Technique with the Kano Model of Customer

\section{Satisfaction}

Thorsten Gruber

The University of Manchester, Manchester Business School, Booth Street West, Manchester M15 6PB, UK, Tel.: +44-(0)161-275 6479 (email: thorsten.gruber@ mbs.ac.uk)

Alexander Reppel,

Royal Holloway, University of London, Egham, Surrey, TW20 0EX, UK, Tel.: +44 (0) 1784 276117 (email: Alexander.Reppel@rhul.ac.uk)

Isabelle Szmigin,

The University of Birmingham, Birmingham Business School, University House,

Birmingham B15 2TT, UK, Tel.: +44-(0)121-414 7357 (email: i.t.szmigin@ bham.ac.uk)

Roediger Voss

Zurich University of Applied Sciences, Department of Life Sciences and Facility

Management, PF 335, 8820 Wädenswil, CH, Tel.: +41-(0)589345754 (email:

roediger.voss@zhaw.ch) 


\section{Structured Abstract}

Purpose - This paper focuses on complaint satisfaction with a particular emphasis on the qualities and behaviours that affect customers during personal complaint handling encounters. Following a literature review of complaint satisfaction and the role of customer contact employees in complaint encounters, an exploratory study using both the laddering interviewing technique and Kano questionnaires is presented.

Design/Methodology/Approach - A semi-standardized qualitative technique called laddering was combined with the Kano Model of Satisfaction. In total, 40 laddering in-depth interviews were conducted with mature students in a business management course. Following the laddering interviews, 35 Kano questionnaires were handed out to students in another business management course who also had complaining experience.

Findings - The laddering results indicate that being taken seriously in the complaint encounter and the employee's friendliness, listening skills and competence are particularly important. The fact that interpersonal factors are highly regarded indicates that customers want to satisfy these process needs first and their outcome expectations second. The Kano results show that employees' active listening skills are the only must-be requirements while the two concepts "Apology" and "Respectful Treatment" are close to being must-be criteria. In addition, the employee's feedback after the complaint handling encounter can almost be categorized as an excitement factor.

Limitations/Originality/Value - By combing two research methods, the aim of this paper has been to develop an area of research that could reap considerable benefits for researchers interested in the area of customer complaint satisfaction. Due to the exploratory nature of the study and the scope and size of the chosen sample, the results outlined are tentative in nature. Keywords: Complaint satisfaction, Laddering technique, Kano model, Service interactions Paper Type Research Paper 


\section{Revealing the Expectations and Preferences of Complaining Customers by Combining the Laddering Interviewing Technique with the Kano Model of Customer Satisfaction}

\section{Introduction}

Despite the negative impact of dissatisfaction and high cost of acquiring new customers (Hart et al. 1990), many companies still assign relatively low priority to dealing with customer complaints, to the extent that customers are often actively discouraged from complaining (Naylor, 2003). Naylor (2003) estimates that fewer than 50 percent of complainants receive a reply from the company and those that do often view the organization's response as unsatisfactory. Similarly, Andreassen (2001) reports that only 30 percent of complaining customers are happy with the company's complaint handling efforts.

\section{Role of Complaint Satisfaction}

Customers who voice their concerns are effectively giving the company a second chance. This is the organization's opportunity to solve the problem such that costs (like negative word-ofmouth, switching behaviour providers and lost turnover), can be prevented or minimized (Stauss, 1999). Research findings reveal that complaint satisfaction can prevent customers from switching to other providers, inhibit negative word-of-mouth communication and even encourage customers to engage in positive communication about the company (HennigThurau, 1999; Stauss, 1999).

Complaint satisfaction is the result of a subjective evaluation process where customers compare expectations with perceptions. Customers should be satisfied if the experience exceeds expectations and dissatisfied if not; theory also suggests that they will be indifferent if their perceptions equal their expectations but one might argue that at the very least the relationship may be maintained in such a situation (Stauss, 2002). Such customer expectations, and in particular desire expectations, have not been extensively researched and 
yet desire expectations are likely to be used as a way of evaluating recovery performance of companies (Yim et al., 2003) as well as being used as reference points for personal satisfaction judgments (Singh and Widing, 1991). In addition, desire expectations are more stable and less dependent on the particular situation than other types of expectations (Zeithaml et al., 1993).

This research investigates how customer contact employees should behave and which qualities they should possess (desire expectations) to deal with customer complaints effectively. Despite the publication of a number of studies since Best and Andreasen published their pioneering work in 1977, Kim et al. (2003) still believe that current understanding of complaint satisfaction is limited. They maintain that the literature on consumer complaints has predominantly concentrated on identifying variables that influence complaining behaviour such as the likelihood of successful redress (Singh, 1990), attribution of blame (Folkes, 1984) or the customer's attitude toward complaining (Richins, 1982). In a similar vein, authors such as Hocutt et al. (2006), Holloway and Beatty (2003) and McCollough et al. (2000) argue that little is known about how customers evaluate recovery efforts and what the potential limits of recovery to convert dissatisfied customers into satisfied ones are. Winsted (2000) maintains that companies will only be able to deliver service encounters that will satisfy customers if they understand the critical contact employee behaviours from a customer's point of view.

\section{The Role of Customer Contact Employees}

Customer complaints are still most likely to be made in person to a contact employee, and so such employees play a crucial role in creating complaint satisfaction. This study suggests that in such face-to-face situations, the perception of the complaint handling encounter and the overall evaluation of the company's complaint resolution process will be largely influenced 
by the employee's response. Such interpersonal service situations offer the greatest opportunity for managing quality (Bearden et al., 1998). Customer contact employees are vital in the recovery from failures (Bell and Luddington, 2006; Kau and Loh, 2006) and play an important role in creating complaint satisfaction. Hartline and Ferrell (1996) suggest that the behaviours and attitudes of customer contact employees primarily determine the customers' perceptions of service quality. Other studies indicate that the human interaction element is essential to determine whether service delivery will be deemed satisfactory (Chebat and Kollias, 2000). Importantly, employees who are competent, able and willing to solve a problem can increase customers' service encounter satisfaction (Bitner et al., 1990). Bitner et al. (1994) recognize that satisfaction is often affected by the nature of the interpersonal interaction between the customer and the contact employee. Similarly, Van Dolen et al. (2004) argue that for retail companies, frontline employees operate before during and after a purchase as the primary point of contact and are key to providing good service.

We suggest that once a company has recognised and understood complaining customers' expectations, then contact employees may be trained to manage their own behaviour so as to respond appropriately to their customers' underlying expectations. Such behaviour should have a positive impact on customer satisfaction (Botschen et al., 1999). Given the current lack of knowledge concerning customer desire expectations (Pieters et al., 1998) and the dimensional structure of complaint satisfaction (Stauss, 1999), an exploratory qualitative research study was conducted. The study aimed to identify the qualities and behaviours of customer contact employees most important for customers during personal complaint handling encounters. The research sought to develop a deeper understanding of the attributes (qualities and behaviours) of effective customer contact employees that complaining customers desire and to uncover the constructs that underlie these desire expectations. 


\section{The Laddering Technique}

We used the laddering technique to reveal the attributes of effective customer contact employees that complaining customers desire. Laddering is generally employed to reveal the relationships which exist between the attributes of products, services or individuals ("means"), what consequences these attributes represent for the respondent, and the personal values or beliefs, which are strengthened or satisfied by the consequences ("end") (Reynolds and Gutman, 1988). Attributes are the tangible and intangible characteristics of a product or service. Consequences are the reasons why a certain attribute is important to the consumer. They are the psychological or physiological results that consumers think they can achieve by using the product or service (Gutman, 1982). Values are the consumers' universal life goals and the most personal and general consequences individuals are striving for in their lives (Rokeach, 1973). Consequences (mid level of abstraction) are more relevant to the self than attributes (low level of abstraction) and values (high level of abstraction) are more relevant to the self than personal consequences (Olson and Reynolds, 1983). Effectively this describes a movement at increasingly higher levels of abstraction to desired ends, reflecting progress from the product to aspects of consumers' self concepts (Gutman, 1997). Although predominately used for brand or product positioning issues (Gutman, 1982; Olson and Reynolds, 1983), laddering has also been recently applied to research areas such as shopping behaviour (e.g. Wagner, 2007), services marketing (Gruber et al., 2006; Voss et al., 2007), and new product development (Reppel et al., 2006).

Laddering usually involves personal semi-standardized in-depth interviews where the interviewer's probing questions are used to reveal attribute-consequence-value chains by taking the subject up a ladder of abstraction. The interviewer repeatedly questions why an attribute, a consequence, and a value is important to the respondent with the answer acting as the starting point for further questioning. Cognitive concepts gleaned during the laddering 
interviews are summarised in a graphical representation of a set of means-end chains known as a Hierarchical Value Map (HVM) (Gengler et al., 1995). An HVM, which is the key outcome of a laddering study, consists of nodes representing the most important attributes/consequences/values (conceptual meanings) and lines, which indicate links between concepts.

\section{The Kano Model of Customer Satisfaction}

Recent customer satisfaction research suggests that attributes of products and services can be classified into three categories, must-be factors, one-dimensional factors and excitement factors, which all affect customer satisfaction and dissatisfaction differently (e.g. Anderson and Mittal, 2000; Matzler et al., 2004; Nilsson-Witell and Fundin, 2005). These originate from Kano's model (1984) categorising customer needs. The model allows researchers to gain a deeper understanding of customer preferences by analysing how they evaluate and perceive product or service attributes. Must-be factors are attributes that customers take for granted and do not increase customer satisfaction. If the product or service, however, does not meet expectations, then customers will be dissatisfied. One-dimensional factors are attributes for which the relationship between attribute performance and (dis)satisfaction is linear. The more (less) an attribute fulfils the requirements, the more (less) customers are satisfied. Excitement factors are attributes that make customers very satisfied or even delighted (Matzler et al., 2004) if products or services achieve these factors fully. Customers are, however, not dissatisfied if products or services do not meet these requirements.

For each attribute, respondents have to answer a question consisting of two parts: How do you feel if the feature is present? (functional form of the question) and how do you feel if the feature is not present? (dysfunctional form of the question) (Berger et al., 1993, p. 5). The 
questionnaire results can then be visualised in a chart that illustrates which attributes are must-be, one-dimensional, and excitement factors.

\section{The Study}

The aim of the present study is to conduct personal laddering interviews and Kano questionnaires to gain a valuable first insight into the attributes of effective customer contact employees that complaining customers desire. There were a number of reasons for our decision to use both research techniques. According to Bharadwaj and Menon (1997) and Lilja and Wiklund (2006), the Kano model does not quantify the performance of the attributes and it also cannot explain why the chosen attributes are of importance to customers. The laddering technique addresses these issues by revealing the reasons why an attribute is important to customers and by displaying the frequency respondents mention a certain concept. The Kano model, however, shows which attributes have the strongest impact on customer (dis)satisfaction. This characteristic of the model is highly valuable for companies as it reveals which attributes add value and increase satisfaction and which attributes only meet minimum requirements (Matzler and Sauerwein, 2002). Companies can then decide for which qualities and behaviours of contact employees they should design effective training programmes to improve employee performance and/or which qualities prospective job candidates for posts with complaint handling responsibilities should possess to handle complaints successfully. The results from laddering interviews alone do not provide managers with this important information.

In total, 40 laddering in-depth interviews were conducted with mature students in a business management course. The respondents who took part on a voluntary basis were all screened to ensure they had complaining experience. At the beginning of each laddering interview respondents were asked to talk about one of their complaining experiences. The idea behind 
this procedure was to show respondents that the interviewer was genuinely interested in their experiences and to accustom them to the complaining context. We then asked all 40 interviewees: "Given that a service or product failure has occurred, what qualities should customer contact employees possess and what behaviours should they exhibit to create complaint satisfaction during personal complaint handling encounters?" If respondents specified more than five to eight attributes or characteristics, we then asked them to rank the attributes in order of preference and we selected those attributes with the highest ratings as suggested by Reynolds and Gutman (1988) and Deeter-Schmelz et al. (2002). This simple technique of direct questioning was sufficient to elicit salient contact employee attributes and characteristics. For the elicitation of attributes, we decided not to ask respondents to think of a specific industrial sector as we were interested in the behaviour and qualities of contact employees and Winsted (2000) discovered that the large majority of behaviours of service employees are the same across different service industries. The derived criteria were the starting point for the laddering probes to uncover the complete means-end structure.

Although several research findings indicate that product or service failure severity has an impact on service recovery/complaint handling encounter evaluations (e.g. Levesque and McDougall, 2000; Mattila, 2001), we still decided not to distinguish between varying levels of service or product failure severity. As stated, we were particularly interested in the complaint handling process and Weun et al. $(2004$, p. 139) found that "the influence of the process of service recovery on post-recovery satisfaction is stable across varying levels of service failure severity". In particular, they discovered that the importance of interpersonal attributes such as friendliness and courtesy "is the same across both major and minor service failures" (Weun et al., 2004, p. 141). McCollough et al. (2000) argue that the severity of a (service) failure is specific to the context and the individual. What one individual considers to be a low-harm failure can be a high-harm failure for another individual. Similarly, Mattila 
(2001) believes that every individual will perceive the seriousness of a failure differently based on both individual and situational factors.

Following the laddering interviews, 35 Kano questionnaires were handed out to students in another business management course who also had complaining experience and who also took part on a voluntary basis. Respondents were for example asked "If a contact employee takes sufficient time to handle your complaint, how do you feel?" (functional form of the question) and "If a contact employee does not treat you respectfully during the complaint handling encounter, how do you feel?" (dysfunctional form of the question). For each question, respondents could then answer in five different ways: 1. I like it. 2. I expect it. 3. I am neutral. 4. I can tolerate it. 5. I dislike it.

\section{Results and Discussion}

The resulting HVM detailing the findings from the personal laddering interviews is illustrated in figure one. It reveals a complex value map, although it only displays associations beyond cutoff level 4, meaning that linkages had to be mentioned by at least 4 respondents to be represented in the map. The size of the circles stands for the frequency respondents brought up a certain concept on this particular cutoff level. Thus, the most important attributes are the contact employees' friendliness, active listening skills (“Active Listening”) and competence.

\section{Take in Figure 1}

Complaining customers want contact employees to be genuinely friendly, courteous, and honest; they need them to give the impression of being motivated and willing to help. Such empathy has been identified as an important factor in strengthening service satisfaction (Bearden et al., 1998) and so in a complaining situation it is also likely to be important. The 
authenticity of the contact employees helpfulness and friendliness is particularly important as respondents believed that they would notice if employees feign friendliness. The frequency with which such attributes were mentioned underlines the importance of employees having a complaint handling orientation. This orientation may be defined as the willingness and inclination to continuously improve complaint handling performance, to make efforts for their customers, and to try to meet customer needs throughout the relationship between the customer and contact employee. This definition is based on a review of existing constructs that are used in both practice and theory such as customer orientation (e.g. Williams and Attaway, 1996), service orientation (e.g. Hogan et al., 1984), customer service orientation (e.g. Alge et al., 2002), and commitment to service (Peccei and Rosenthal, 1997) and emphasizes the need for deep organisational commitment and support for the customer contact person.

Complaining customers also wanted contact employees to be competent. If frontline employees are perceived as competent then customers believe they will deal appropriately with their problem and ultimately resolve it. Such competency requires them to be knowledgeable about the product or service and to have the authority to handle customer problems adequately (decision-making competence). Complaint handling competence is a resource that contact employees bring to the complaint handling encounter and that does not depend on the complaining customer's input during the encounter (Jaccard et al., 1989; Van Dolen et al., 2004). In particular, respondents wanted employees to have sufficient product or service knowledge and prior experience to interact successfully with them. This reflects the work of Becker and Wellins (1990) who found that customers want employees to have both an understanding of the company's products and services as well as those policies and procedures that relate to customer service.

Customer contact employees also need to listen actively to the complaining customer. If employees listen actively, customers judge that the employee is taking them and their 
complaint seriously. The importance of "Active Listening" supports findings from the personal selling and sales management literature which suggests that an employee's listening behaviour plays an important role for personal interactions (e.g. De Ruyter and Wetzels, 2000; Ramsey and Sohi, 1997). Contact employees who listen actively receive, process, and respond to messages in such a way that further communication is encouraged. Such individuals pay attention to both the speaker's verbal and nonverbal cues and they are also capable of providing both verbal and nonverbal feedback by using all their senses (Comer and Drollinger, 1999).

The most frequently mentioned consequences were "Take Someone Seriously" and "Problem Solution" and respondents felt they were taken seriously if contact employees listened actively, solved the problem and were courteous, honest, and empathetic. As the width of the line in the HVM reveals, "Take Someone Seriously" is strongly associated with several values. Analysis of the value map also reveals that respondents needed their complaint to be taken seriously; an employee who is friendly and actively listens should help to support this. In addition, contact employees need to show effort ("Motivation"), to solve the problem and to compensate customers for the costs they have incurred ("Solution").

Several values relevant to this process such as, self-esteem, well-being, justice, satisfaction, and security, were raised and above all, respondents wanted fair treatment (“Justice”). The importance of fair treatment supports findings by Voorhees and Brady (2005) who suggest that companies should treat their customers fairly throughout the failed service encounter and not only during the recovery process. This requires organisations to recruit only individuals who are genuinely willing to help and to act on the behalf of their complaining customers. Respondents mentioned that a speedy complaint resolution ("Speed") would help them save time which would make them feel happy and in good hands ("Well-Being"). Before handling and eventually solving the problem, contact employees, however, should take sufficient time ("Take Time") to listen to what their complaining customer has to say. 
Complaining customers also want to develop trust with contact employees so that they have certainty and are freed from doubt ("Security").

As mentioned, the elicited attributes from the laddering interviews were then used to develop a Kano questionnaire. We also included three more concepts "Apology", "Responsibility", and "Feedback" (marked as triangles in Figure 2) in the questionnaire that only a few respondents mentioned during the laddering interviews and which did not appear in the corresponding HVM due to the chosen cutoff level. As the definitions of the three concepts "Active Listening", "Competence", and "Solution" covered several different aspects, we had to break down each of these three concepts into two separate statements. The concept “Competence”, for example, covers both employees' service (product) knowledge (COMPETENCE I) as well as their authority to handle customer problems adequately (COMPETENCE II).

The Kano map in figure 2 illustrates which employee attributes are must-have factors that customers take for granted, one-dimensional factors for which the relationship between attribute performance and (dis-)satisfaction is linear, and excitement factors that delight customers. The map reveals that the majority of employee attributes are one-dimensional factors, with courtesy having the strongest impact on satisfaction, followed by the two complaint solution attributes and employees' motivation.

\section{Take in Figure 2}

Employees have to be honest as customers are otherwise not surprisingly extremely

dissatisfied. The map also shows that the contact employees' ability to listen carefully to what their customers are saying is the only must-be requirement. The fulfilment of this requirement does not increase customer satisfaction notably. However, if employees do not listen carefully, then customers will be very dissatisfied. Thus, while it may be argued that 
complainants take this employee attribute for granted it is a very important attribute to get right. The Kano map also shows that the two concepts "Apology" and "Respectful Treating" are close to being must-be criteria. Similarly, the employee's feedback after the complaint handling encounter, to identify whether the customer is satisfied with the resolution is almost an excitement factor that satisfies customers but that does not increase customer dissatisfaction if employees do not get back to their customers. These results reinforce the need for companies to recruit only individuals who are genuinely willing to help and to act on the behalf of their complaining customers. Companies should train employees in how to treat customers respectfully but above all employees must know how to listen carefully.

\section{Conclusion}

In the context of long term profitability, companies have to ensure that the management of relationships with dissatisfied customers and contact employees operates effectively. Customer complaint satisfaction is a crucial area for managers and academics alike to focus upon and better understand, especially in the context of such long term profitability, and, the success of the company's relationships with customers and the management of employees. Importantly, the voicing of concern indicates customers' willingness to maintain the relationship (Hirschman, 1970) and companies should make the most of getting a second chance as most dissatisfied customers do not complain and exit the service instead (Bodey and Grace, 2006) with some recounting their experiences to warn their friends and family (Lerman, 2006). Companies who have not as yet understood this, urgently need a revolution in their thinking and management such that they no longer regard customer complaints as annoying. Companies must respect consumers' rights (East, 2000) and regard customer complaints as a valuable source of information for them to improve their services or products (McCole, 2004). 
This exploratory study has provided an important insight into the desired behaviours and qualities of customer contact employees to create customer complaint satisfaction in face-toface complaint handling encounters. The laddering interviews have shown that above all complaining customers need to be taken seriously and respected as individuals. The fact that interpersonal factors such as friendliness, respectful treatment and listening skills are important, indicate that customers want to satisfy these basic process needs first and their expectations and consumption or complaint handling needs come second. This supports recent findings by Chebat et al. (2005) who also stress the importance of companies dealing with customer emotions first. The analysis of the Kano questionnaires revealed that complaining customers take the contact employee's ability to listen carefully to what they have to say during the complaint handling encounter for granted, indicating that its absence will have serious results for the company.

By applying two methods new to this context, the aim of this paper has been to develop an area of research and methodology that could reap considerable benefits for researchers interested in the area of customer complaint satisfaction. Expectations of complaint handling are likely to affect how customers evaluate a service firm as much as their expectations of the original service and it is therefore vital for the firm the firm to explore these (Burgers et al. 2000). Research should also focus on the attributes of contact employees (excitement factors) that can create not only complaint satisfaction but even complaint delight so that companies, especially those in highly competitive markets, can stand out from the competition. 


\section{References}

Alge, B. J., Gresham, M. T., Heneman, R. L., Fox, J. and McMasters, R. (2002), “Measuring customer service orientation using a measure of interpersonal skills: a preliminary test in a public service organization", Journal of Business and Psychology, Vol.16 No. 3, pp. 467-476.

Anderson, E. W. and Mittal, V. (2000), "Strengthening the satisfaction-profit chain", Journal of Service Research, Vol. 3 No. 2, pp. 107-120.

Andreassen, T. W. (2001), “From disgust to delight: do customers hold a grudge?", Journal of Service Research, Vol. 4 No. 1, pp. 39-49.

Bearden, W.O., Malhotra, M.K. and Uscategui, K.H. (1998) "Customer contact and the evaluation of service experiences: propositions and implications for the design of services", Psychology \& Marketing, Vol. 15 No. 8, pp. 793-809.

Becker, W.and Wellins, R. (1990), “Customer service perceptions and reality”, Training and Development Journal, Vol. 44 No. 3, pp. 49-51.

Bell, S. J. and Luddington, J. A. (2006), “Coping with customer complaints”, Journal of Service Research, Vol. 8 No. 3, pp. 221-233.

Berger, C., Blauth, R., Boger, D., Bolster, C., Burchill, G. DuMouchel, W., Pouliot, F. Richter, R., Rubinoff, A., Shen, D., Timko, M. and Walden, D. (1993), “Kano’s methods for understanding customer-defined quality", The Centre for Quality Management Journal, Vol. 2 No. 4, pp. 3-36.

Best A. and Andreasen A.R. (1977), “Consumer responses to unsatisfactory purchases: a survey of perceiving defects, voicing complaints and obtaining redress”, Law and Society Review, Vol. 11, Spring, pp. 701-742. 
Bharadwaj, S. and Menon, A. (1997), “Discussion in applying the Kano methodology to meet customer requirements”, Quality Management Journal, Vol. 4 No. 3, pp. 107-109.

Bitner, M. J., Booms, B. H. and Tetreault, M. S. (1990), “The service encounter: diagnosing favorable and unfavorable incidents", Journal of Marketing, Vol. 54 No.1, pp. 71-84.

Bitner M. J, Booms, B. H. and Mohr L. A. (1994), “Critical service encounters: the employee's viewpoint", Journal of Marketing, Vol. 58 No. 4, pp. 95-106.

Bodey, K. and Grace, D. (2006), "Segmenting service "complainers" and "non-complainers" on the basis of consumer characteristics", Journal of Services Marketing, Vol. 20 No. 3, pp. 178-187.

Botschen, G., Thelen, E. M. and Pieters, R. (1999), "Using means-end structures for benefit segmentation”, European Journal of Marketing, Vol. 33 No. 1/2, pp. 38-58.

Burgers, A. de Ruyter, K., Keen, C. and Streukens, S. (2000), “Customer expectation dimensions of voice-to-voice service encounters: a scale-development study", International Journal of Service Industry Management, Vol. 11 No. 2, pp.142-161

Chebat, J-C., Davidow, M. and Codjovi, I. (2005), “Silent voices. Why some dissatisfied consumers fail to complain", Journal of Service Research, Vol. 7 No. 4, pp. 328-342.

Chebat, J-C. and Kollias, P. (2000), “The impact of empowerment on customer contact employees' roles in service organizations", Journal of Service Research, Vol. 3 No. 1, pp. 66-81.

Comer, L. B. and Drollinger, T. (1999), “Active empathetic listening and selling success: a conceptual framework”, Journal of Personal Selling \& Sales Management, Vol. 19 No. 1, pp. 15-29.

De Ruyter, K. and Wetzels, M. (2000), “The impact of perceived listening behavior in voiceto-voice service encounters", Journal of Service Research, Vol. 2 No. 3, pp. 276-284. 
Deeter-Schmelz, D. R., Kennedy, K. N. and Goebel, D. J. (2002), “Understanding sales manager effectiveness - linking attributes to sales force values", Industrial Marketing Management, Vol. 31 No. 7, pp. 617-626.

East, R. (2000), “Complaining as planned behavior”, Psychology \& Marketing, Vol .17 No. 12, pp. 1077-1095.

Folkes, V. S. (1984), “Consumer reactions to product failure: an attributional approach”, Journal of Consumer Research, Vol. 10 No. 4, pp. 398-409.

Gengler, C. E., Klenosky, D. B. and Mulvey, M. S. (1995), "Improving the graphic representation of means-end results", International Journal of Research in Marketing, Vol. 12 No. 3, pp. 245-256.

Gruber, T., Szmigin, I. and Voss, R. (2006), “The desired qualities of customer contact employees in complaint handling encounters", Journal of Marketing Management, Vol. 22 No. 5-6, pp. 619-642.

Gutman, J. (1982), “A means-end chain model based on consumer categorization processes”, Journal of Marketing, Vol. 46 No. 2, pp. 60-72.

Gutman J. (1997), "Means-end chains as goal hierarchies”, Psychology \& Marketing, Vol. 14 No. 6, pp. 545-560.

Hart, C. W. L., Heskett, J. L. and Sasser Jr, W. E. (1990), “The profitable art of service recovery", Harvard Business Review, Vol. 68 No. 4, pp. 148-156.

Hartline, M. D. and Ferrell, O. C. (1996), “The management of customer-contact service employees: an empirical investigation”, Journal of Marketing, Vol. 60 No. 4, pp. $52-$ 70.

Hennig-Thurau, T. (1999), "Beschwerdezufriedenheit: empirische analyse der wirkungen und determinanten einer schlüsselgröße des beziehungsmarketing“ [Analysing the 
determinants and consequences of complaint satisfaction], Jahrbuch der Absatz- und Verbrauchsforschung, Vol. 45 No. 2, pp. 214-240 (in German).

Hirschman, A. O. (1970), Exit, Voice and Loyalty, Harvard Press, Cambridge, MA.

Hocutt, M. A., Bowers, M. R. and Donavan, D. T. (2006), “The art of service recovery: fact or fiction?”, Journal of Services Marketing, Vol. 20 No. 3, pp. 199-207.

Hogan, J., Hogan, R. and Busch, C. M. (1984), "How to measure service orientation", Journal of Applied Psychology, Vol. 69 No. 1, pp. 67-173.

Holloway, B. B. and Beatty, S. E. (2003), "Service failure in online retailing - a recovery opportunity”, Journal of Service Research, Vol. 6 No. 1, pp. 92-105.

Jaccard, J., Brinberg, D. and Dittus, P. (1989), “Couple decision making: individual- and dyadic-level analysis”, in: Brinberg, D. and Jaccard, J. (Eds.), Dyadic Decision Making, Springer, New York, NY, pp. 36-50.

Kau. A. K. and Loh, E. W-Y. (2006), “The effects of service recovery on consumer satisfaction: a comparison between complainants and non-complainants", Journal of Services Marketing, Vol. 20 No. 2, pp. 101-111.

Kano, N. (1984), “Attractive quality and must be quality”, Hinshitsu (Quality), Vol. 14 No. 2, pp. 147-156 (in Japanese).

Kim, C., Kim, S., Im, S. and Shin, C. (2003), "The effect of attitude and perception on consumer complaint intentions", Journal of Consumer Marketing, Vol. 20 No. 4, pp. $352-371$.

Lerman, D. (2006), “Consumer politeness and complaining behavior", Journal of Services Marketing, Vol. 20 No. 2, pp. 92-100. 
Levesque, T. J. and McDougall, G. H. G. (2000), “Service problems and recovery strategies: an experiment", Canadian Journal of Administrative Sciences, Vol. 17 No.1, pp. 2037.

Lilja, J. and Wiklund, H. (2006), "Obstacles to the creation of attractive quality", The TQM Magazine, Vol. 18 No. 1, pp. 55-66.

Mattila, A. S. (2001), "The effectiveness of service recovery in a multi-industry setting", The Journal of Services Marketing, Vol. 15 No. 7, pp. 583-596.

Matzler, K. and Sauerwein, E. (2002). “The factor structure of customer satisfaction: an empirical test of the importance grid and the penalty-reward-contrast analysis", International Journal of Service Industry Management, Vol. 13 No. 4, pp. 314-332.

Matzler, K., Fuchs, M. and Schubert, A. K. (2004), “Employee satisfaction: does kano’s model apply?", Total Quality Management, Vol. 15 No. 9-10, pp. 1179-1198.

Matzler, K., Bailom, F., Hinterhuber, H. H., Renzl, B. and Pichler, J. (2004), “The asymmetric relationship between attribute-level performance and overall customer satisfaction: a reconsideration of the importance-performance analysis", Industrial Marketing Management, Vol. 33 No. 4, pp. 271-277.

McCole, P. (2004), "Dealing with complaints in services", International Journal of Contemporary Hospitality Management, Vol. 16 No. 6, pp. 345-354.

McCollough, M. A., Berry, L. L. and Yadav, M. S. (2000), “An empirical investigation of customer satisfaction after service failure and recovery", Journal of Service Research, Vol. 3 No. 2, pp. 121-137.

Naylor, G. (2003), “The Complaining customer: a service provider's best friend?, Journal of Consumer Satisfaction, Dissatisfaction and Complaining Behavior, Vol. 16, pp. 241248. 
Nilsson-Witell, L. and Fundin, A. (2005), “dynamics of service attributes: a test of Kano’s theory of attractive quality", International Journal of Service Industry Management, Vol. 16 No. 2, pp. 152-168.

Olson, J. C. and Reynolds, T. J. (1983), “Understanding consumers' cognitive structures: implications for marketing strategy", in Percy, L. and Woodside, A. G. (Eds.), Advertising and Consumer Psychology, Lexington Books, Lexington, MA, pp. 77-90.

Peccei, R. and Rosenthal, P. (1997), “The antecedents of employee commitment to customer service: evidence from a UK service context", International Journal of Human Resource Management, Vol. 8 No. 1, pp. 66-86.

Pieters, R., Botschen, G. and Thelen, E. M. (1998), "Customer desire expectations about service employees: an analysis of hierarchical relations", Psychology \& Marketing, Vol. 15 No. 8, pp. 755-773.

Ramsey, R. P. and Sohi, W. S. (1997), "Listening to your customers: the impact of perceived salesperson listening behavior on relationship outcomes", Journal of the Academy of Marketing Science, Vol. 25 No. 2, pp. 127-137.

Reppel, A., Szmigin, I. and Gruber, T. (2006). "The iPod phenomenon: identifying a market leader's secrets through qualitative marketing research", Journal of Product \& Brand Management, Vol. 15 No. 4, pp. 239-249.

Reynolds, T. J. and Gutman, J. (1988), "Laddering theory, method, analysis and interpretation", Journal of Advertising Research, Vol. 28 No. 1, pp.11-31.

Richins, M. L. (1982), “An investigation of consumer attitudes toward complaining”, in Mitchell, A. (Ed.), Advances in Consumer Research, Association for Consumer Research, Provo, UT, pp. 502-506.

Rokeach, M. J. (1973), The Nature of Human Values, Free Press, New York, NY. 
Singh, J. (1990), "Voice, exit, and negative word-of-mouth behaviors: an investigation across three service categories", Journal of the Academy of Marketing Science, Vol. 18 No.1, pp. 1-15.

Singh, J. and Widing II, R. E. (1991), "What occurs once consumers complain? - a theoretical model for understanding satisfaction/dissatisfaction outcomes for complaint responses", European Journal of Marketing, Vol. 25 No.5, pp. 30-46.

Stauss, B. (1999), “Kundenbindung durch beschwerdemanagement [Customer retention through complaint management], in Bruhn, M. and Homburg, C. (Eds.), Handbuch Kundenbindungsmanagement [The customer retention management handbook], 2nd Edition, Gabler Verlag, Wiesbaden, pp. 213-238 (in German).

Stauss, B. (2002), “The dimensions of complaint satisfaction: process and outcome complaint satisfaction versus cold fact and warm act complaint satisfaction”, Managing Service Quality, Vol. 12 No. 3, pp. 173-183.

Van Dolen, W., De Ruyter, K. and Lemmink, J. (2004), “An empirical assessment of the influence of customer emotions and contact employee performance on encounter and relationship satisfaction”, Journal of Business Research, Vol. 57 No. 4, pp. 437-444.

Voorhees, C. M. and Brady, M. K. (2005), “A service perspective on the drivers of complaint intentions", Journal of Service Research, Vol. 8 No. 2, pp. 192-204.

Voss, R., Gruber, T. and Szmigin, I. (2007). "Service quality in higher education: the role of student expectations", Journal of Business Research, Vol. 60 No. 9, 949-959.

Wagner, T. (2007), "Shopping motivation revised: a means-end chain analytical perspective", International Journal of Retail \& Distribution Management, Vol. 35 No. 7, pp. 569582. 
Weun, S., Beatty, S. E. and Jones, M. A. (2004), “The impact of service failure severity on service recovery evaluations and post-recovery relationships", Journal of Services Marketing, Vol. 18 No. 2, pp. 133-146.

Williams, M. R. and Attaway, J. S. (1996), 'Exploring salespersons' customer orientation as a mediator of organizational culture's influence on buyer-seller relationships", Journal of Personal Selling \& Sales Management, Vol. 16 No. 4, pp. 33-52.

Winsted, K. F. (2000), "Service behaviors that lead to satisfied customers", European Journal of Marketing, Vol. 34 No. 3/4, pp. 399-417.

Yim, C. K., Gu, F. F., Chan, K. W. and Tse, D. K. (2003), “Justice-based service recovery expectations: measurement and antecedents”, Journal of Consumer Satisfaction, Dissatisfaction and Complaining Behavior, Vol. 16, pp. 36-52.

Zeithaml, V. A., Berry L. L. and Parasuraman, A. (1993), “The nature and determinants of customer expectations of services", Journal of the Academy of Marketing Science, Vol. 21 No. 1, pp. 1-12. 


\section{Figures}

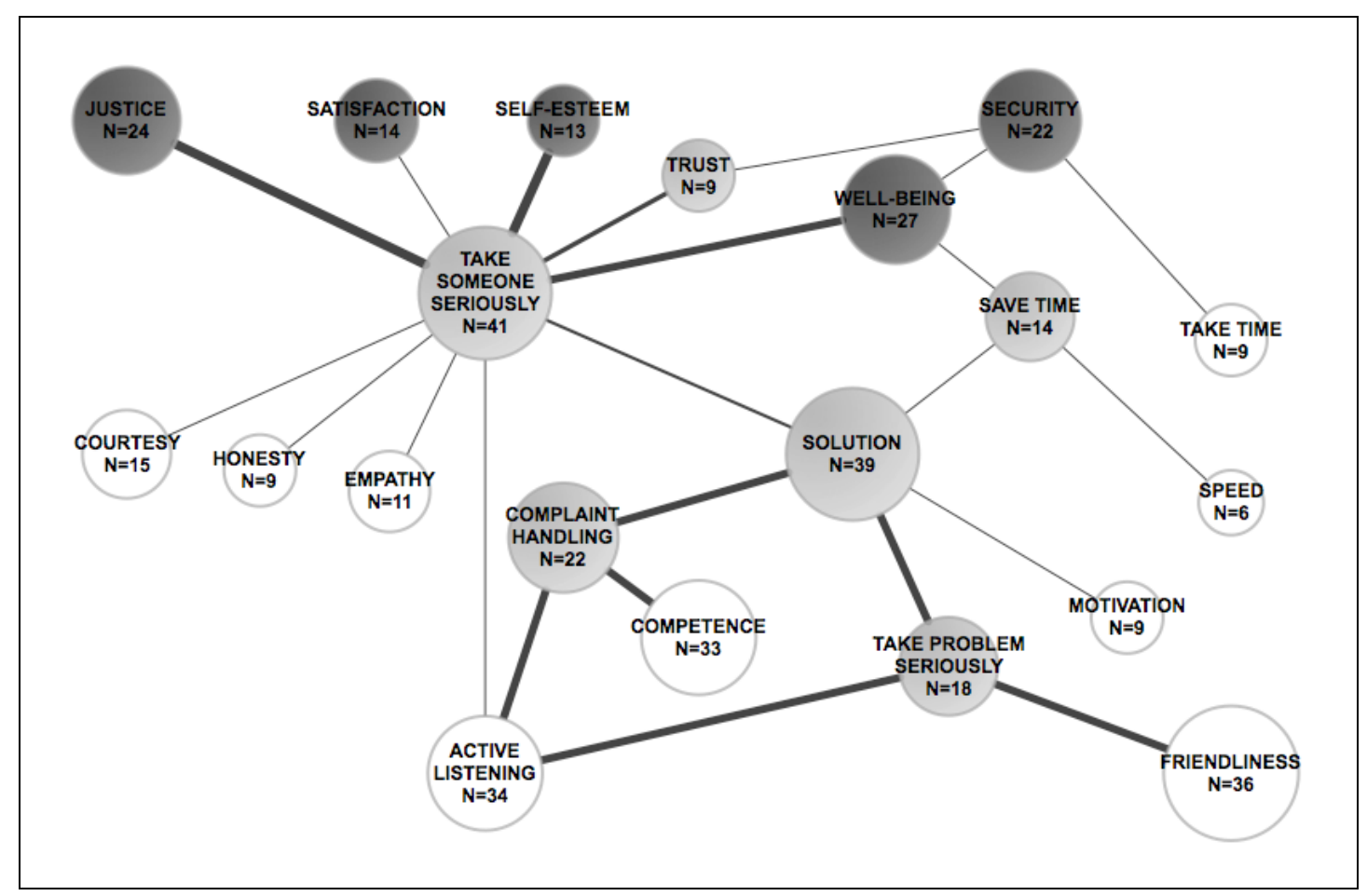

Figure 1. HVM (attributes=white, consequences=grey and values=black)

Numbers $(\mathrm{N})$ refer to concepts revealed in the ladders and not to the number of respondents 


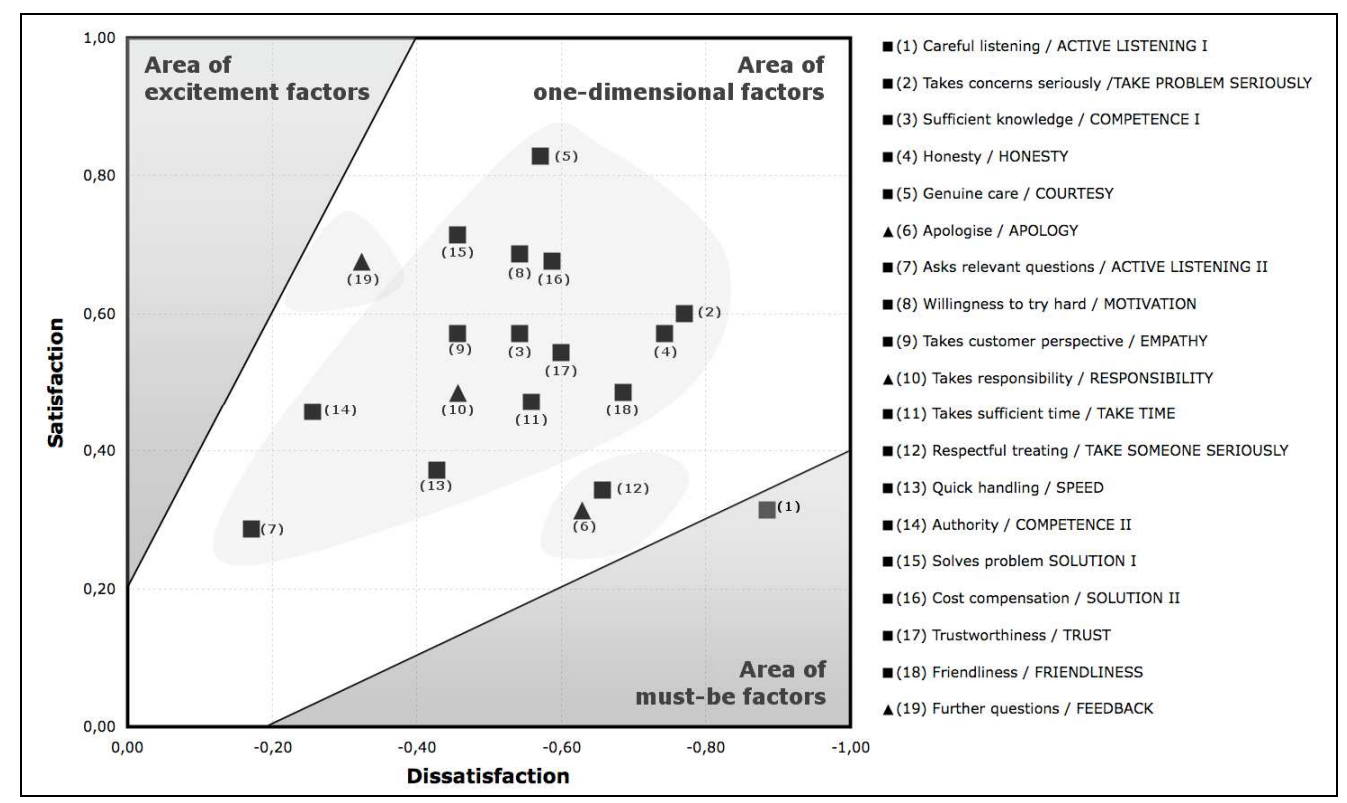

Figure 2. Influence of Employee Attributes on Satisfaction and Dissatisfaction 